\title{
соціологія
}

UDC 327

\section{THE DECLINE AND FALL OF BRITISH POWER}

\author{
Chris Weston \\ $P h D$, \\ President at Weston Consulting (Warsaw)
}

The purpose of this paper is to examine the decline and fall of British power. "Power" is defined as the ability to influence another party and Michael Mann's four sources of social power is employed as an analytical tool.

While on the face of it Britain possesses a number of indicators which suggest that it is a major power, it is argued that those indicators may not reveal the full extent of the decline of British power over a period of time and which has been accentuated by the outcome of the Brexit referendum in June 2016.

The downward trajectory of power is examined through the prism of two examples. The first concerns Korea and Britain's involvement in the war of 1950-1953 but also through the influence of Britain's then prime minister with the US President over the defence of Europe as well as lobbying the US on its threatened use of nuclear weapons. The contrast with the British stance on the latest crisis on the peninsular could not be starker and the silence of the British government reflects the fall of British influence notwithstanding claims to the contrary post referendum of a "Global Britain".

The second example concerns Britain's situation post fall of the Berlin Wall, post Gulf War and even post Masstricht Treaty (which saw Britain secure several opt outs from the European Union) and its role in 1994 in securing the territorial integrity of Ukraine. British influence might be viewed as still significant although the ejection from the Exchange Rate Mechanism - a blow to its Political Power and Economic Power - was a modest harbinger of its vulnerability to economic crises - an all too familiar theme of its modern history. The events post Crimean occupation and post invasion of Eastern Ukraine witnessed the UK absent from the ensuing negotiations which were led by Germany and France from the European side. The UK was already withdrawing into itself from its (relatively modest political although not insignificant defence) role in Europe, let alone a Global role it purported to aspire to.

The curves of both events intersect at a point on a downward trajectory.

The paper, in addition to Mann's Four Sources of Social Power, is supplemented by the introduction of his fifth - "Leadership" as well as considering the use of the intelligence services, which constitute a blend of both political and military instrumentality employed to achieve a desired set out of outcomes to protect its interests and further its aims in the global order. The paper also considers the interstices of the various sources. In particular, attention is drawn to the fifth source noted by Mann - that of "Leadership" and that British sources of social power had particularly diminished during the Cameron and May governments and with it, its strategic outlook.

The paper is the first in a series that will examine the Decline \& Fall of British Power since 1945.

Метою статті є пояснення занепаду й падіння могутності Британії. У той час як Великобританія демонструє низку показників, які свідчать про її міць, у статті стверджується, що ці показники можуть не розкривати всю масштабність падіння британської влади протягом певного періоду часу, що було підкреслено результатом чергового референдуму в березні - червні 2016 року. Як аналітичний інструмент застосовується теорія джерел соціальної влади Майкла Манна. У роботі також розглядаються межі між різними джерелами соціальної влади. Зокрема, звертається увага на п'яте джерело, зазначене М. Манном, - «лідерство», а також на те, що британські джерела соціальної влади були особливо ослаблені за уряду Д. Кемерона та травневого референдуму.

Ця стаття $є$ першою в серії, присвяченій вивченню падіння й занепаду влади/потужності Британії з 1945 року.

Целью статьи является объяснение упадка и падения мощи Британии. В то время как Великобритания демонстрирует ряд показателей, которые свидетельствуют о ее мощи, в статье утверждается, что эти показатели могут не раскрывать всю масштабность падения британской власти в течение определенного периода времени, что было подчеркнуто результатом очередного ресререндума в марте - июне 2016 года. В качестве аналитического инструмента применяется теория источников социальной власти Майкла Манна. В работе также рассматриваются границы между различными 
источниками социальной власти. В частности, обращается внимание на пятый источник, указанный М. Манном, - «лидерство», а также на то, что британские источники социальной власти были особенно ослаблены при правительстве Д. Кэмерона и майском референдуме.

Эта статья является первой в серии, посвященной изучению падения и упадка власти/мощи Британии с 1945 года.

Key words: Britain, power, sources of social power, Leadership.

\section{Introduction}

The purpose of this paper is to examine the decline and fall of British power. "Power" is defined as the ability to influence another party. Michael Mann has argued that there are four sources of power as: economic, political, military, ideological [15].

Mann in the course of his four works on this has also outlined a fifth source of power - that of Leadership [16]. He mentions this in passing and asides from a number of examples - such as Napoleon and Bismarck - otherwise the point is moot. I remain hesitant to diverge from this assumption for a number of reasons. Foremost is that it may give undue prominence to certain persons and a wish to avoid the "Scylla and Charybdis" situation of engaging in hagiography on one side and outright denigration on the other. If I may betray bias, it is towards that of attributing a fair amount of criticism all round and on a cross party basis as I will argue both the leading parties in the UK and their leaders have contributed to the current position the UK faces.

\section{Balance sheet of Power}

On the face of it - at first appearance, the UK still enjoys a measure of power on the world. Taking the relevant sources above and excluding for the moment the "Ideological" source, we can note the following position of the UK in the international order:

- UK accounts for $12,8 \%$ of population and $16 \%$ of GDP of total EU;

- Number 5 economy in world with USD 2,6 trillion (IMF, UN, WB) - 2016;

- Member of NATO; one of few to have met 2\% spending limit; nuclear weapons;

- Intel and Defence interests: member of "Five Eyes"1 agreement with major sigint and surveillance assets; respected intelligence services (MI5/SIS'; Top 10 ranking as military power ${ }^{3}$ ); Germany);

- IMF member - 4,04\% shareholding; (with France, largest shareholder after USA, China and

- UN Security Council member with veto power;

- "London is the most competitive financial centre in the world" - ranking 2015.

Just a few comments on the above. As a result of the referendum on 23 June 2016, the UK voted to exit the European Union after just forty years of membership. A lack of clarity on "what happens next?" led to sterling depreciating against foreign currencies of around 15\%. The UK's dollar denominated GDP dropped accordingly such that the UK became the sixth largest economy in the world by the end of $2017^{4}$.

That said, while GDP and indeed GDP per capita are useful indicators, they are not without their limitations and their deficiencies have been dealt with elsewhere ${ }^{5}$. The UK's economic performance post World War II has been a mixed bag to say the least and other leading members of the EU, such as Germany, France and even Italy (for a period) have enjoyed better indicators. The OECD has recently announced that the UK's economic performance outlook for 2018 will be among the lowest of its members [7].

The inclusion of intelligence services and their assets may appear odd at first appearance. They do not really appear in the Mann analysis as a separate "source" of power but it is argued that it may well be unwise to ignore this for a number of reasons both specific to the UK and general in terms of how intelligence services can constitute an important sub category of both "political" and "military" power which operating either individually on separate tracks or on their own or, in certain circumstances, combined, can serve both to amplify existing sources and achieve particular outcomes of both a positive and negative nature. They also constitute a deliberate means of securing "economic" power.

\footnotetext{
This refers to an intelligence alliance comprising Australia, Canada, New Zealand, the United Kingdom and the United States for cooperating in collection of signals intelligence. The UK responsible body is GCHQ based in Cheltenham but with several foreign installations as well.

2 MI5 handles domestic security and counterespionage; SIS is the foreign intelligence service.

See: https://www.globalfirepower.com/countries-listing.asp (for 2017).

See: http://www.imf.org/external/pubs/ft/weo/2017/02/weodata/weorept.aspx.

I will argue in a later paper that GDP measures are just a small part of what constitutes Economic Power. Other constituents can be how the UK derived its wealth: the sugar trade, slave trade, opium trade, the destruction of local manufactures and looting of India, its colonial ties, the involvement in BP and the Middle East, the leading role of the City of London and also its historic as well as ongoing role in the world's financial architecture through its joint creation with the USA of the Bretton Wood institutions of $1944-$ the UK is still a leading shareholder in the IMF.
} 
A separate facet to also be considered is that of "Leadership" in terms of the use of intelligence, assuming of course it has been obtained in the first place by whatever means. This has been examined by Aldrich in his work which has examined the exploitation, to various degrees, of intelligence by British prime ministers since Asquith up to David Cameron [2].

An example of this dovetailing of military, political, economic sources as well as of intelligence services can be found in the events leading up to the coup in 1953 in Iran that unseated the country's Prime Minister, Mohammad Mosaddegh. In this instance, Britain's leading oil company, BP was a major contributor to the British economy [8, p. 48]. The nationalisation of its oil interests in Iran thus constituted a singular blow to the Britain's economic power, through diminished share of profits and critically for a country perennially troubled by currency problems, a major source of foreign exchange $\mathrm{e}^{6}$; as well as political power through the Iranian government asserting its interests in political sovereignty encouraging other Middle Eastern countries to consider taking control of their oil resources or indeed other British colonies pursuing political independence.

A naval embargo - encompassing the threatened use of military power - against Port Abidjan, the major oil refinery and transportation hub in Iran in September 1951 (under the then Labour government entering its twilight period in office and replaced with a Conservative government under Churchill from 26 October 1951) had not led to a resolution. A British intelligence operation - codenamed Boot - developed by SIS using both human assets in the Iranian military, parliament, business, press and religious sectors and disbursement of money would be folded into a latter joint CIA-SIS operation - codenamed Ajax - which would see the unseating of Mossadegh in August 1953 and the restoration of the Shah to the throne (the Shah would later fall from power in 1978 following the Iranian Revolution).

\section{The UK's trajectory of power: 2 Case studies}

A problem in considering contemporary issues is to become lost in the myriad of detail and reports, thereby losing perspective and to avoid the means to frame particular events or occurrences in their particular context. This can be also influenced by personal bias - a consideration of the present through current dislikes and prejudices - or even a predisposition to idealise (or possibly idolise) past events and even personalities.

In his four-volume The Pride and Fall series [4] the British historian, Corelli Barnett, traced the decline of British power during the twentieth century up to 1950. In these works, Barnett noted the relevant dissipation of (to borrow from Mann again) the economic, military and political sources of power available to Britain (as supplemented by failing to take advantage of technology) as crystallised in a poor strategic position post 1945 and their impact on British "values"; and indeed the negative feedback loop from "values" onto the relevant sources of power. The "values" affected were essentially those of the governing classes in Britain. It is worth bearing in mind that while the governing classes in 1950 would constitute the ruling Labour government (elected in a landslide in 1945) under Atlee, Barnett has allocated a considerable amount of blame to all of the ruling parties whether they be Conservative, Liberal and Labour (and indeed coalitions thereof at points in time).

\section{The Korean peninsular: a far away country of which we know little?}

One of the examples neatly follows this chronological order and takes place in 1950. On 25 June 1950, the armed forces of North Korea invaded South Korea. The United Nations Security Council unanimously condemned the invasion with UN Security Council Resolution 82. At the time, the members of the Council were the USA, UK, France and the USSR. As the USSR had disputed the fact that the People's Republic of China had not been allowed to take up its seat on the council following Mao's victory in that country's civil war in 1949, it had boycotted the UN proceedings. The USSR's absence had permitted the other three members - the USA, UK and France, to implement resolution 83 which allowed member states to provide military assistance to the Republic of Korea without the USSR being able to wield its veto.

The then President Truman faced an invasion of its ally on the Korean peninsular whilst also a significant potential threat from the Soviet Union in Europe. Thus, as a means to counter any moves in the latter, he ordered the deployment of nuclear capable bombers to US bases in the UK.

The retreat of South Korean and the limited US forces to the south of the peninsular threatened to overwhelm them before UN forces came to their assistance. Thus, Truman threatened the use of nuclear weapons to attack both the North Koreans and deter Chinese involvement.

The British involvement in the Korean War was undertaken through a military component - the $1^{\text {ST }}$ Commonwealth Division; and a naval force including an aircraft carrier.

A statement by Truman that the use of nuclear weapons were always an option led to the then British prime minister Atlee decision to fly to Washington for consultations with Truman.

A biographer of Atlee has noted that the meeting between the two constituted a "frank representation of differences in strategy and international policy (which) undoubtedly helped prevent hostilities in Korea escalating into a wider conflict, possibly a Third World War" [11, p. 447, 462]. Of interest was Atlee seeking

\footnotetext{
6 And least we forget: the era of cheap oil would help underpin the West's economic development (or "Economic" power) from this time right up until the 1970s before the 1973 OPEC price increases and the Iranian Revolution of 1978-1979.
} 
to talk down the US from use of nuclear weapons on the peninsular and against mainland China, encouraging are entry onto mainland China of the defeated Nationalist forces as well as avoiding a diversion of attention from the European theatre whose security and stability might be compromised. There was also an agreement that the British would participate in any decision to use nuclear weapons. It was considered unlikely that Churchill could have obtained as much from such talks.

The Trump Presidency and the Brexit vote have led to the UK displaying both passivity and silence as events unfurled on the Korean peninsular. The recourse by Trump to visiting "fire and fury" on North Korea and threats to employ nuclear weapons on the peninsular in some form of pre emptive attack - the so called "bloody nose" strike scenario [12] - elicited barely any response from the British government.

The FCO briefing on North Korea stated the following: "Tensions are high due to the number of missile launches carried out by DPRK and the threat of further missile or nuclear tests. There were 2 nuclear tests in 2016 and 1 in 2017, a series of ballistic missile tests in 2016 and 2017, 2 intercontinental ballistic missile tests in July 2017 and 1 in November 2017". There was no reference to the US itself contributing to these tensions ${ }^{7}$. The author was present in DPRK in July and noted no such tensions in his interactions with the North Koreans.

The Foreign Secretary, not known for maintaining a diplomatic silence on anything of consequence or indeed anything at all, has been as "quiet as a church mouse" on Korea8.

There is case to be made - see also the next case study - that the UK government was silent due to its poor situation arising from the Brexit referendum. Whilst President Obama was adamant in the run up to the referendum that the UK would need "to be at the back of the line" for such negotiations. The Trump administration has made more encouraging noises. Given Trump's stated intent to ensure that only the US should enter agreements on its own zero-sum terms and therefore for its sole benefit, it is a measure of the UK's weak position as well as the government's desperation to portray such a trade deal as within its grasp that it is prepared to sustain the fiction of a truly "Global Britain" post Brexit. Observers have noted that such trade deals can take a decade or so to negotiate and then to be ratified by a Congress not averse to pursuing the interests of business donors and special interests. The "Special Relationship" is thus likely to be realised under this new trading arrangement in the flood of food and drug products that otherwise do not meet EU standards and the dismantling of the National Health Service [10].

Of interest is that UK pushback to Trump has focused on relatively modest domestic matters such as disclosure of details concerning the Manchester bombing and the President's retweeting of videos of doubtful provenance by an extreme right British organisation enjoying negligible popular support ${ }^{9}$.

British self absorption with the Brexit process has led it to disengage from possible EU based initiatives to mitigate tensions on the Korean peninsular. Thus, one means of the European Union wishing to pursue negotiations, in a format based on the P5+1 talks which led to an agreement with Iran on its pursuit of nuclear weapons, has not emerged given the UK's unwillingness to cross Trump on his Korea outbursts and its antipathy to a European dimension for conducting foreign policy. After all, the exit from the institutions of the European Union also led to its withdrawal of British personnel from the European External Action Service - the EU's diplomatic service and foreign and defence ministry in which it was well represented.

Johnson's poor performance in this role has attracted critical comments: "All over the world the geopolitical tectonic plates are shifting yet at this time of huge global significance the foreign secretary is all but invisible on the international stage. On the nuclear threat posed by North Korea, the crisis over Saudi Arabia and Qatar or the clash between the US and China, he is irrelevant. On Syria, Afghanistan, Iraq, Iran, Russia, Venezuela, Turkey and Yemen, he is incoherent" [19].

\section{Absent without leave on Ukraine}

The absence of the UK during the course of the Ukraine Crisis in 2014 was a more serious harbinger of the extent of the decline and fall of UK power since, unlike the Korean problems whose then-and-now

\footnotetext{
7 See: https://www.gov.uk/foreign-travel-advice/north-korea/safety-and-security (Accessed 18 February 2018). The author visited the DPRK for three weeks in July 2017.

8 The present incumbent, Boris Johnson, is viewed as one of the weakest foreign secretaries in living, and probably distant, memory. Again it is measure of the poor state of the Conservative Party and its internal management that this leading cabinet position has been allocated to an individual temperamentally unsuited and ill qualified to occupy. The fact that the Brexit process is essentially being handled by Downing Street/Cabinet office, as well as the newly established Department for Exiting the Economic Union and the Department for International Trade is perhaps a reflexion of the Prime Minister's wish to distance Johnson as much as possible from the Brexit process, whose intricate details and sheer bureaucratic nitty-gritty would overwhelm him.

9 Trump's handling of confidential top secret information is a story in itself. It has been noted that he disclosed to the Russians in the White House information gleaned by the Israeli Mossad from a high level source in Islamic State much to the Israeli's considerable annoyance over this breach of protocol. Trump's approach to intelligence can be contrasted with a number of his predecessors which has been set out in [3]. According to Wolff, in his book on the Trump presidency with respect to intelligence briefings: "(Trump) seemed to lack the ability to take in third-party information. Or maybe he lacked the interest; whichever he seemed almost phobic about having formal demands on his attention. He stonewalled every written page and balked at every explanation". Trump's riposte to the Syrians employing chemical weapons by a cruise missile attack on Al Shayrat airbase was prompted by his daughter, Ivanka, putting together a presentation of pictures of victims of the chemical attack rather than any intelligence briefing [20, p. 114, 119].
} 
narrative bookmarked 1950 and 2017, the problems took place just before the EU referendum in 2016 and constituted an abdication from a position which the UK had entered into only in 1994 with its signature on the Bucharest Agreement whereby it undertook to preserve the territorial integrity of this country.

Before considering the nature of the UK's signing up to the Bucharest Agreement, some background on the state of affairs in the 1990s. Following the resignation of Margaret Thatcher from the premiership in November 1990, John Major became prime minister. Major was thrust almost immediately into the Middle East crisis where Iraq had invaded Kuwait and, as a consequence, the US and an alliance of nations (with the UK providing the second largest component in the then ongoing military buildup) poised to launch Desert Storm in March 1991 which would see the Iraqi military driven back to within its own borders in a crushing defeat.

Major would thus be able to bask in a military victory of consequence and successfully negotiated the Maastricht Treaty in November 1991 which secured a number of opt outs from the then ongoing European project for an "ever closer union". Thus, in the abstract, Military Power had secured "dividends" in both avoiding a diminution in Economic Power which might ensue with Iraq controlling Kuwaiti oil reserves and threatening the stability of the oil market via its armed presence in proximity to Saudi oil reserves, as well as an enhanced Political Power in terms of demonstration of British military abilities and a willingness to honour commitments. The UK had committed military forces to Kuwait to prevent a then perceived Iraqi threat of invasion in 1962. Kuwait had since become a significant source of oil supplies as well as a major investor in the UK.

Major's increased stature, combined with an opposition leader still facing questions over his suitability for prime minister, proved sufficient to win the General Election and secure the Conservative Party its four consecutive electoral victory by winning 14 million votes and the most votes in British electoral history.

But within a short period, Major's premiership, like the Ozymandias figure of Percy Shelley's poem, had turned to dust ${ }^{10}$. On 16 September 1992, known as "Black Wednesday", Britain was humiliatingly ejected from the Exchange Rate Mechanism which it had joined and committed to protect the rate of sterling against wide exchange rate variations. While the UK enjoyed a reasonable economic recovery after its withdrawal and reduced unemployment, it was to be a "never glad confident morning again" for Major's government as splits in the party - eerily familiar in the events playing out in May's government today and even involving some of the same faces - and sleaze undermined its credibility. In the 1997 general Election, the Conservative Party would suffer the worst electoral defeat by a ruling party since the Reform Act of 1832 .

Of note is that it was later reported that SIS had a high-ranking source in German government financial circles in the period preceding Black Wednesday [2, p. 402]. The Bundesbank, under its then head, Otto Pohl, were a key decision maker in the fate of the UK's continued membership of the ERM. It appears that while the intelligence services were able to provide the relevant information, the British government seemed to convince itself that the German Chancellor Kohl could override the independence of the Bundesbank to effect a helping hand over sterling's problems. This wishful thinking stumbled over the established institutional underpinnings of Germany's independent central bank which prized its arms - length distance from politicians. The episode revealed the golden rule that intelligence is often only as good as the end person making the ultimate decisions based thereon. Historical examples such as Chamberlain in the run up to Munich in 1938 and latter day instances in the run up to the Iraq War would lend credence to this rule ${ }^{11}$.

At the then OSCE conference held in Budapest on 5 December 1994, the UK had joined other nuclear powers such as the USA and the Russian Federation in providing security assurances against threats or the use of force against the territorial integrity or political independence of Ukraine, in return for the latter voluntarily giving up nuclear weapons. Both China and France offered lesser assurances in separate memoranda.

In February 2014, forces of the Russian Federation seized Crimea and annexed the territory on 1 March. Both constituted flagrant breaches of the Budapest Memorandum. While initially portrayed as a homegrown domestic disturbance culminating in armed conflict in Eastern Ukraine by the Russian Federation, this fiction became ever more difficult to maintain given the considerable influx of Russian military

\footnotetext{
10 The second verse proceeds as follows: "And on the pedestal these words appear:

"My name is Ozymandias, king of kings;

Look on my works, ye Mighty, and despair!'

Nothing beside remains. Round the decay

Of that colossal wreck, boundless and bare

The lone and level sands stretch far away".

In a ranking of 19 Prime Ministers, Major came in at number 17 [18] It is most probable that the ranking may change given it omits Cameron and May who have not distinguished themselves in office as well as even Blair and Brown. That said, a new book reappraising Major by Hickson and Williams still left the questionmark lingering in its title.

${ }_{11}$ In due course it will be interesting to observe how the intelligence services provided input to the May government over the Brexit negotiations with the EU-27 and the European Commission and its lead negotiators. I would predict that they will have delivered the right product but that it will not overcome the often insurmountable obstacle of poor political leadership. See Aldrich et al, op cit, for his critical assessment of prime ministers and their adeptness in the handling of intelligence. There is a certain measure of correlation between the BBC ranking above with that of Aldrich's assessment.
} 
units, as protected by Russian airpower and surface to air missiles, hardware and other paraphernalia, to aid separatist units. That would become nigh impossible after the shooting down of Malaysian airplane $\mathrm{MH}-17$ by a Russian surface to air missile fired by a Russian military unit deep inside Ukrainian territory.

In the aftermath of these events, it therefore became of interest how the relevant signatories would react. The first item of interest is when the USA and UK governments became aware of the military moves being undertaken by Russia. Of particular salience is whether the British intelligence services had picked up any indicators on its own account. Here it is worth considering whether the austerity measures imposed by the then Coalition government on all departments (including SIS) had also been compounded by a diversion of resources to counter the threat of Islamic State emanating from Iraq and Syria, plus the ongoing Afghan-Pakistan conundrum ${ }^{12}$ to blind the UK to this emerging threat from the Russians. On one side, this remains difficult to believe given their history of animosity between the two dating back to the 1917 Revolution and even during the Yeltsin and Putin period, the British intelligence establishment had taken note of an illegal bio weapons programme, the Litvinenko case [9] (an assassination in 2006 on British soil, no less, with nuclear substances), the invasion of Georgia in 2008 and subsequent annexation of Abkhazia and South Ossetia ${ }^{13}$, cyberattacks on numerous countries in Central Europe, cutting off oil supplies et al.

It has been the seeming hesitation of the government to react and initiate sanctions that warrants a closer look. In particular, contrary to Corelli Barnet's assertion that British politicians of the nineteenth and twentieth centuries had failed to look at the "bottom line" and act accordingly - a dubious proposition in the light of how all postwar British governments of all complexions vigorously pursued all sources of power to protect the country's perceived Economic Power - the Cameron government was undoubtedly pursuing rational economic calculation ahead of deciding how to react to events in Crimea and Eastern Ukraine which constituted a major threat to Europe's peace and stability.

Indeed, one of the aspects that the British government needed to pay attention to was BP, whom we have met before in the context of Iran in the early 1950s and which was undoubtedly a key contributor (at least historically) to Britain's Economic Power ${ }^{14}$. At the time, BP faced major financial issues in respect of its culpability for the Deepwater Horizon catastrophe where its oil rig in the Gulf of Mexico had exploded and then led to the largest oil spill in the history of the petroleum industry. As of February 2013, criminal and civil settlements and payments to a trust fund had cost BP USD 42,2 billion.

On 8 December 2014, the US Supreme Court rejected BP's legal challenge to a compensation deal over the oil spill. The settlement agreement had no cap, but BP initially estimated that it would pay roughly USD 7,8 billion to compensate victims. Later, in July 2015, BP agreed to pay a further USD 18,7 billion in fines, the largest corporate settlement in US history.

Throughout this period, BP faced an immense challenge in terms of disposing of its assets to generate cash to meet the everincreasing claims arising from the Gulf of Mexico oil spill. In October 2012, BP sold its stake in its Russian joint venture TNK-BP to Rosneft for USD 12,3 billion in cash and an $18,5 \%$ stake in Rosneft - a leading Russian oil company built from the remains of Yukos which had been bankrupted by the Russian state and its CEO/founder Khordokovsky jailed and which was run by Igor Sechin, a well known Kremlin insider and crony of Vladimir Putin. The deal struck by BP was completed on 21 March $2013^{15}$.

The TNK-BP had been a major contributor to BP's bottom line: BP had invested USD 8 billion in 2003 but had taken out USD 19 billion in dividends. A full exit which might have netted it a further USD 27 billion from Russia was unfeasible and BP had agreed to invest in Rosneft. This deal, then, was the best that BP could possibly achieve in the circumstances. But it meant that USD 15 billion of capital - more than

\footnotetext{
2 Seventeen years after their introduction into Afghanistan, there are still 600 British troops serving in the theatre engaging in training local forces and special operations against the Taliban [5]. Pakistan plays a complex game of enabling the Taliban in their armed conflict while providing occasional tip offs to the UK regarding British citizens of Pakistani descent training with the myriad of terrorist groups supported and trained by the Pakistani military with whom the UK has close relations. Pakistan is also of interest given its involvement in the notorious $A Q$ Khan nuclear proliferation smuggling ring as well as its ever increasing nuclear arsenal.

13 Again, as with Eastern Ukraine and Crimea, the UK appears to have remained silent on the Georgia situation as indeed did the Bush administration in its waning days in office as it sought to contain the deepening Financial Crisis. Henry Paulson, the US Treasury Secretary, in his memoirs, reports that he became aware from Chinese contacts of a Russian approach to Beijing to enlist them in taking advantage of the crisis to further destabilise the USA's financial system. The Chinese declined to get involved. The question remains as to whether the USA essentially declined to defend its purported ally, Georgia, due to these Russian threats? Or did it unwittingly allow the Russians to believe that they could blackmail the USA this way? The Russians did not believe that US/EU sanctions would be forthcoming or remain in place long after Crimea so it begs the question whether given its lethargic and craven attitude re Georgia, the West would also not react to the occupation of Crimea and invasion of Eastern Ukraine. Despite the Litvinenko killing, the UK also seems to have "pulled its punches" in 2008 following the invasion of Georgia with again a possible belief taking hold in the Kremlin that it could enjoy a "free ride". The Syrian fiasco of non enforcement of "red lines" by the UK and USA in 2013 would have reconfirmed that judgement.

14 BP would later encourage the UK and Scottish government to release a Libyan imprisoned for involvement in the Lockerbie bombing of a PanAm plane due to the warming relations with Libya's leader Gadaffi and BP's interest in accessing the Libyan oil reserves. BP merits a book about it in the vein of Steve Coll's book on Exxon [6].

15 See: https://web.archive.org/web/20140214072516/http://uk.reuters.com/article/2013/03/22/uk-rosneft-tnkbp-deal-idUKBRE92K0IX20130322 (accessed 19 February 2018).
} 
$10 \%$ of BP's market value, was hostage to the whims of the Kremlin [17]. Furthermore, BP's bottom line was heavily reliant on the Rosneft contribution, as noted below, in the years 2014 to 2016 (USD millions) ${ }^{16}$ :

\begin{tabular}{|c|c|c|c|}
\hline & 2016 & 2015 & 2014 \\
\hline Profit/(Loss) before tax and interest & 430 & $(7,918)$ & 6,412 \\
\hline Rosneft contribution & 647 & 1,314 & 2,076 \\
\hline Rosneft/PBIT (\%) & 150,5 & $-{ }^{*}$ & 32,4 \\
\hline
\end{tabular}

* This means that without the Rosneft contribution, BP's Loss before Interest and Tax would have amounted to USD 9,2 billion

BP's ability to survive and to keep paying the bills from the Gulf of Mexico were thus in the hands of parties who might not look kindly on the UK seeking to honour its commitment to Ukraine's territorial integrity.

In addition, as was also noted by Ben Judah [14], London and the UK's south east had become susceptible to, and reliant on (addicted to?) considerable infusions of "funny money" from Russia, particularly in the financial and real estate sectors (known as "FIRE"), as well as legal services for which a number of City law firms relied on. The City of London in its longstanding role as the world's leading financial intermediary in taking a percentage of the tens of billions of pounds "washing" through its financial institutions. The real estate industry - a major component of the UK given the importance of rising housing prices to a significant part of the population - also benefitted from infusions of Russian cash into the property market ${ }^{17}$.

The UK government initially appeared hesitant in its initial response but soon fell into line with the EU and the USA. Notwithstanding its initial commitment to the Budapest Memorandum, the UK preferred to "lead from behind" on the Ukraine crisis and then proceeded to outsource the negotiations of the Minsk agreements to the German and French governments.

The former head of SIS, Sir John Sawers would note that: "Germany and France were actively involved in dealing with the crisis in Ukraine, and the Russian intervention there. Britain wasn't really in the room".

Sawers has also pointed to the Cameron government of 2010 onwards when the UK's power diminished [13]. He highlighted a number of factors that contributed to this: the aftermath of the Iraq and Afghan wars; the former of which had been launched under dubious circumstances among allegations of over exaggeration of Iraq's weapons of mass destruction potential, politicised intelligence to serve government purposes, inadequate attention to the aftermath and naivety about the intentions of Iran in the region with Saddam's removal ${ }^{18}$.

A further influence was the consequences of the 2008 Global Financial Crisis. This is noteworthy given that one of the few plaudits that Gordon Brown deserved as prime minister was his attention to the international dimensions of the crisis and enhancing cooperation within the G-20 body to offset the real likelihood of a global depression through concerted action. Sawers points to the Cameron coalition government and its introduction of austerity measures and the adoption of a more insular outlook that inhibited British power.

To this was added poor leadership of Cameron in respect of the unfurling Syrian crisis and "the red line that never was" in the employment of chemical weapons by the Assad regime against civilian opponents. Sawers notes that Cameron wanted to "duck his responsibility" by allowing the House of Commons a vote on whether to launch retaliation. He did not get his votes and in the USA, President Obama also sought to disown his own "red line" by seeking congressional approval. Neither man emerged with much credit from this affair and their propensity for inaction was duly noted by the appropriate parties in the Kremlin and Zhongnanhai.

This aspect of poor leadership has also been accentuated by the conduct of Theresa May as prime minister following the resignation of Cameron following the result of the Brexit referendum in June 20161'. Sawers (diplomatically) noted of May that she is not "a natural at engaging on these big political issues with foreign leaders".

\footnotetext{
16 See Note 5, p. 145-146: https://www.bp.com/content/dam/bp/en/corporate/pdf/investors/bp-annual-report-and-form-20f-2016.pdf (accessed 18 February 2018).

17 "In the central London borough of Westminster, almost one in ten properties is owned by an anonymous offshore company and can't be directly associated with a specific owner" [18].

A further facet is the opportunity provide of Russians raising finance in the London capital markets. For example, Oleg Deripaska, an oligarch closely linked to Putin and still subject to an entry ban by the USA for his alleged ties to organised crime, recently raised over GBP 1 billion for one of his entities [1].

18 Indeed, Colin Powell in his speech on 5 February 2003 to the UN making the case for war against Iraq referred to British intelligence (presumably SIS) obtaining information regarding the supply of nuclear materials from Niger to Iraq which was later found to be incorrect. The latter point re Iran has been borne out by events with Iraq's Shiite government becoming almost a wholly dominated satellite of Tehran to the alarm and consternation of its (largely Sunni) neighbours. Indeed the removal of the Taliban in 2001 in another country neighbouring Iran, Afghanistan, has also emboldened Iranian influence there. Surely this cannot have been what either the USA or UK intended when they invaded Iraq?

19 Indeed since Cameron surprisingly won the General Election on 7 May 2015 and therefore felt obliged to honour his promise of a referendum on continuing EU membership, Britain's diplomatic and other resources were squandered in a forlorn yearlong tour around the capitals of Europe seeking a figleaf for Cameron to declare victory and recommend a vote to remain in the EU. He failed. Cameron's Panglossian politics of "all will be best in the best of all worlds" would be followed in due course by May's Micawber like politics of "waiting for something to turn up".
} 


\section{Conclusions}

We have sought to employ Mann's Four Sources of Power, as supplemented by the introduction of his fifth - "Leadership" as well as considering the use of the intelligence services, which constitute a blend of both political and military instrumentality to achieve a desired set out of outcomes which for the UK has represented for it a particular strategic result to protect its interests and further its aims in the global order.

We have noted that poor "Leadership" has often contributed to a diminution of three sources of social power namely: economic, military and political. And indeed the converse when Major benefitted from the first Gulf War victory in furthering Political and Economic Power and achieving a favourable strategic outcome in Maastricht Treaty. However, the country's weakening Economic Power and its ejection from the ERM diminished perceived Political Power within the country even if the UK still could project Political and Military Power externally to sign on to the Budapest Memorandum.

We have in passing also considered the role of BP, as a contributor to the country's Economic and Political Power during the 1950s whose role in Iran led to the UK employing its intelligence services to sustain its critical position.

It is argued by reference to the Korean War - perhaps representing the apogee of post war British power - as well as the UK's position in the post Cold War and post Gulf War international landscape - that British sources of social power had diminished during the Cameron and May governments and with it its strategic outlook. The Brexit decision had merely reinforced a trend underway in 2010 and exacerbated by poor leadership and poor policy decisions. The competence and standing of the intelligence services had been impaired by both the Iraq War and Austerity and without other complementary actions were unlikely to accomplish anything.

The sources of UK's Economic Power had left it exposed to potentially revanchist powers such as Russia and China and its financial services and property sectors had been shown to cut both ways.

Further papers will, in the same vein, consider the following:

- Did the UK make the right choices open to it in the period post 1945 to maximise its strategic position based on the then endowment of sources of social power and instruments available to it?

- Has the UK allowed an ideology akin to "nostalgia illusion" affected its choices to squander its other sources of social power?

- Did its failure to pursue a leadership of Europe post 1945 impact its sources of social power? Was Britain ever really in a position to play "Greece to America's Rome" as its prime minister Macmillan noted?

- Was it that the British Empire basis of the country's wealth ultimately the cause of its breakdown of power?

\section{References}

1. Ambrose J. Oleg Deripaska to list energy group En+ in London. The Telegraph. 2017. URL: https://www.telegraph.co.uk/business/2017/10/05/oleg-deripaska-list-11bn-energy-group-en-london/ (accessed: 19.02.2018).

2. Aldrich R., Cormac R. The Black Door. London: William Collins, 2017. 624 p.

3. Andrew C. For The President's Eyes Only: Secret Intelligence and the American Presidency from Washington to Bush. New York: Harper Perennial, 1996. 688 p.

4. Barnett C. The Collapse of British Power. London: Eyre Methuen, 1972. 500 p.

5. Bunkall A. Afghan security: Britain "should commit more troops". SkyNews. 2018. URL: https://news.sky.com/story/afghan-security-britain-should-commit-more-troops-11257283 (accessed: 19.02.2018).

6. Coll S. Private Empire: Exxon Mobil and American Power. London: Penguin, 2013. 704 p.

7. Chu B. UK economy to slow rapidly in 2018 as hard Brexit looms, OECD forecasts. Independent. 2017. URL: https://www.independent.co.uk/news/business/news/uk-economy-growth-forecast-latestupdates-hard-brexit-leave-eu-2018-projected-oecd-a7956776.html (accessed: 21.09.2017).

8. Curtis M. Secret Affairs. Serpents Tail: Profile Books, 2018. 512 p.

9. Cowell A. The Terminal Spy. London: Doubleday, 2008. 448 p.

10. Eaton G. The trade delusion: why Brexit won't be Britain's salvation. NewStatesman. 2018. URL: https://www.newstatesman.com/politics/uk/2018/02/trade-delusion-why-brexit-won-t-be-britainssalvation (accessed: 19.02.2018).

11. Harris K. Attlee. London: Weidenfield, 1995. 520 p.

12. Hurst D. Former US military commander warns against "bloody nose" strike on North Korea. The Guardian. 2018. URL: https://www.theguardian.com/world/2018/feb/20/former-us-military-commanderwarns-against-bloody-nose-strike-on-north-korea (accessed: 20.02.2018).

13. Jay E. Former MI6 Head John Sawers: Brexit could pose long-term problems for British security. Prospect. 2018. URL: https://www.prospectmagazine.co.uk/politics/former-mi6-head-john-sawersbrexit-could-pose-long-term-problems-for-british-security (accessed: 18.02.2018). 
14. Judah B. Fragile Empire. New York: USA Yale UP, 2014. 578 p.

15. Mann M. The Sources of Social Power. Volume 1. Cambridge: CUP, 2012. 578 p.

16. Mann M. The Sources of Social Power. Volume 2. Cambridge: CUP, 2012. 844 p.

17. Pratley N. Taking a stake in Rosneft is a big gamble for BP. The Guardian. 2012. URL: https://www.theguardian.com/business/nils-pratley-on-finance/2012/oct/22/stake-rosneft-gamble-bp (accessed: 18.02.2018).

18. Smirnova O. Just who owns what in central London. BBC. 2016. URL: https://www.bbc.com/news/ business-35757265 (accessed: 19.02.2018).

19. Sylvester R. Our foreign secretary is an international joke. The Times. 2017. URL: https://www.thetimes.co.uk/ article/our-foreign-secretary-is-an-international-joke-7707q0z66 (accessed: 29.08.2017).

20. Wolff M. Fire and Fury: Inside the Trump White House. London: Little Brown, 2018. 336 p. 